\title{
Level of Internet use among the Students of College of Nursing, Pravara Institute of Medical Sciences, Loni (Bk), Maharashtra India
}

\author{
Jitendra D Belokar* \\ Asst Professor, Mental Health Nursing, Pravara Institute of Medical Sciences (Deemed to be University) \\ College of Nursing, Loni (Bk), Maharashtra, India
}

Submission: April 19, 2018; Published: April 26, 2018

*Corresponding author: Jitendra D Belokar, Asst Professor, Mental Health Nursing, Pravara Institute of Medical Sciences (Deemed to be University), College of Nursing, Loni (Bk), Maharashtra, India, Email: jitubelokar@yahoo.com

\begin{abstract}
Background: Internet has special status in science and technology. The history of internet begins with the development of electronics computers in the 1950s. The statistics show that nine to fifteen million individuals use the internet on a daily basis. The mobile sector in India has grown more than ten folds from 2001 to around 60 million subscribers by mid 2005. Internet is being integrated as part of our everyday's life because the usage of internet has been growing explosively worldwide. Homes, schools, colleges, libraries and internet cafes are the places which are more accessible to internet now days. Along with advantages there are harmful effects and disadvantages of internet use3. This study was undertaken to assess level of internet use among students of College of Nursing PIMS at Loni (Bk).
\end{abstract}

Materials and Methods: A descriptive design with cross sectional survey approach was used to collect the data. A standardized scale developed by Dr. Kimberly Young was used to collect data. The samples were selected by non-probability convenient sampling technique. The samples comprised of 60 students of a selected college at Loni (Bk), Maharashtra. Descriptive and inferential statistics was used for data analysis.

Results: The findings of the study revealed that majority of the subjects i.e. $43.33 \%$ were average internet users, $35 \%$ of them were occasional internet users, $21.66 \%$ were least internet users.

Conclusion: Average internet use was seen among most of the subjects. The pattern of use would not lead them harmful effects to their health status.

Keywords: Level Of Internet Use; Students; Selected College.

\section{Introduction}

The internet use by students has increased dramatically in recent years and also surfing the internet has become an important part of general student life. Furthermore, information technologies (IT) have greatly expanded into the field of education in last two decades. There are so many advantages of internet like powerful search engines, information at various levels of study, students can get everything from scholarly articles and can discuss on any topic, they can develop ability to get wide range of opinions. Students can also find others that have a similar interest in whatever they are interested in. The internet provides the ability of emails. Free mail service to anyone in the country. Friendships and love connections have been made over the internet by students involved in love/passion over similar interests [1]. It may lead excessive use and can cause addiction to it. To prevent this, it is now necessity to identify the level of internet use among students and accordingly to develop strategies for appropriate use it. A study conducted to assess internet usage among dental students at a private dental institution in India revealed that $5.7 \%$ and $4.1 \%$ of the students used the internet daily for general and dental purposes respectively [2].

A study conducted to determine use of internet for academic purposes among students in malaysian institutions of higher education revealed that the participants made use of internet on daily basis for about t 4.48 hours per day and there were significant differences in the time spent using the internet among students in different fields of study [3]. In another study based on review of literature by Kumar and kaur revealed that students are the most frequent users of the internet. They use the internet mainly for educational purposes rather than entertainment [4]. Biradar conducted a study on internet usage by the students and faculties in Kuvempu University. The results indicated that $42.1 \%$ of students use internet twice a week and $31.25 \%$ faculties use it every day [5]. Laite surveyed 406 graduate and undergraduate students from Shippensburg University. The survey revealed 
that $57.6 \%$ of the undergraduate students use the internet $1-2$ times per week and another $37.1 \%$ use it $1-2$ times daily. $54.7 \%$ of the undergraduate students used internet 1-2 times per week and $37.7 \%$ used it $1-2$ times daily. The survey showed that the most used internet service was E-mail. $100 \%$ of the graduates and undergraduates used e-mail services [6]. Studies on the use of internet by Jagboro showed that $38.24 \%$ and $22.06 \%$ of the university students use it on weekly and daily basis respectively. Also $11.76 \%$ use the internet monthly and bi-monthly basis [7].

\section{Methodology}

The purpose of this study was to assess the level of internet use among students of College of Nursing PIMS at Loni (Bk), Maharashtra. The descriptive study design with cross sectional survey approach was used to collect data. Total 60 study samples were selected by non probability convenient sampling technique. Data collection was done with tool was divided into two sections. Section A was of demographic profile of the participants comprised of 08 items related to age, gender, educational level, family type, religion, monthly income, area of residence and access to internet facility. Section B was the standardized tool to assess level of internet use which was prepared by Dr. Kimberly Young, consisted of 20 items that measured least, average, occasional or frequent use of internet. Prior permission was obtained from concerned authority of a selected college. During data collection the researcher introduced himself to the respondents and their willingness for the participation was ascertained. The respondents were assured that the confidentiality of the information will be maintained. The informed consent was obtained from the respondent before the data collection. The researcher himself collected data from each subject with interview technique. The data collected from each subject was recorded systematically and organized in a way that facilitated computer entry and data analysis.

\section{Findings}

\section{Findings Related to Demographic Profile of the Participants}

It was found that highest percentages of participant's i.e. $68.33 \%$ were in age group of to $18-20$ years. Majority of $51.66 \%$ respondents were males and $48.33 \%$ were females. Majority of $2^{\text {nd }}$ year students were involved in the study i.e. $45 \%$, Majority of them belonged to nuclear family i.e.77\%, Hindu's were highest among the samples i.e. $91.66 \%$ and $76.66 \%$ of students had self device to access internet.

\section{Principal Findings}

Majority of the participants (43\%) were average internet users, $35 \%$ of them were occasional internet users and $21.66 \%$ were least internet users (Figure 1).

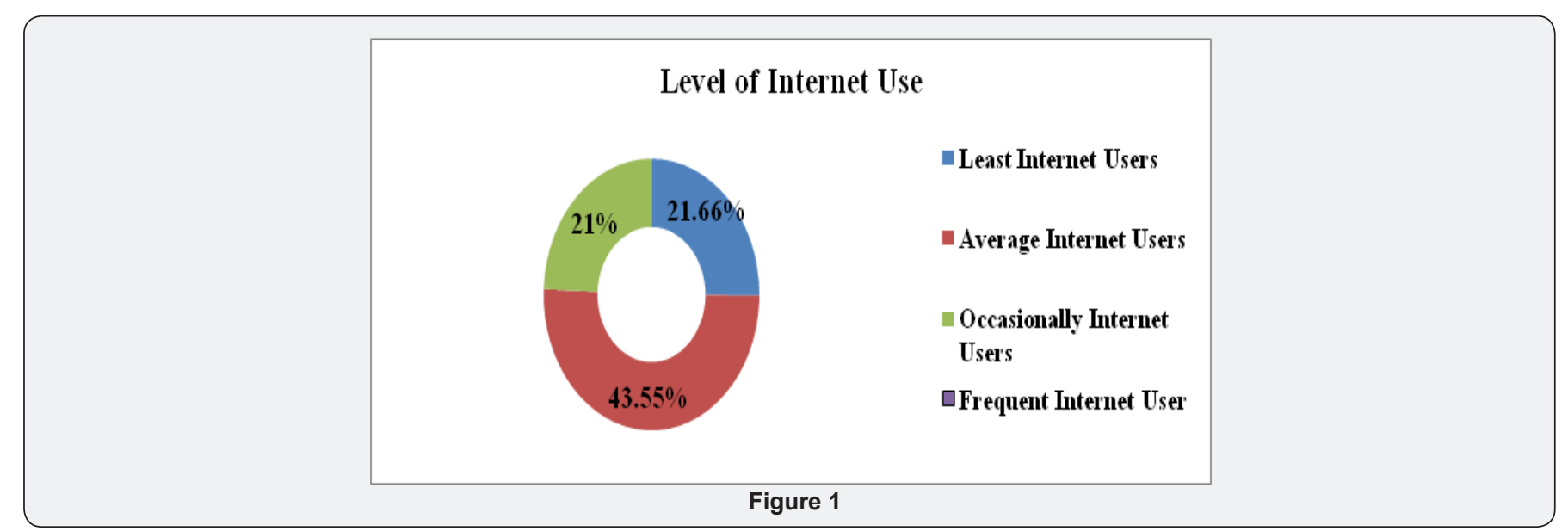

\section{Discussion}

Present study findings are supported by the study titled "Internet Use among University students" conducted by Dr. Nitin Ratan Roy where internet use by participants was twice in a week which was found to be $20 \%$ [9]. A study which was conducted by Ahmad Fauzi Mohd Ayub to determine use of internet for academic purposes among students in Malaysian institutions of higher education indicated that on an average, the participants accessed the Internet 4.48 hours per day [10] which is congruent to present study findings. Pevic in his study reported that teenagers liked to use cybercafés because of their social dimensions, regardless of their access to the Internet at home or in the school [11] which support the findings of present undertaking which is revealing that in spite of not having easy access to internet around
$23.34 \%$ of participants are using internet. Williams in his project "Information Technology in Michigan: Adult and teen Survey Report." Indicated that the majority of the respondents (72\%) used the internet at least once a week and $45 \%$ at least once a day which led significance to present study [12].

\section{Recommendations}

a) Comparative studies can be done in urban and rural area for the pattern of internet use among students

b) Exploratory studies can be conducted on Use of Internet among student population.

c) A study can be conducted on different categories of professional students. 
d) An interventional studies can be carried out on levels of internet addiction

\section{Implications}

Different short term study programmes are to be designed and developed for the students to make them more familiar with safe internet use which will enable them to make more specific and appropriate use of internet.

\section{References}

1. http://mwnation.com/dont-believe-everything-on-the-internet-3/.

2. (2013) Indian J Psychiatry 55(2): 140-143.

3. http://www.girardslaw.com/library/GLOBALADDICTION_Scales InternetAddictionTest.pdf.

4. Chongtham Beda, DeviNil Ratan (2012) Roy Internet Use among University Students: A Case Study of Assam University Silchar.
5. (2014) TOJET: The Turkish Online Journal of Educational Technology 13(1): 233-234.

6. http://shodhganga.inflibnet.ac.in/bitstream/10603/45678/2/c2.pdf.

7. Durkin K (1997) Misuse of the Internet by pedophiles: Implications for law enforcement and probation practice. Federal Probation 61(3): 1418.

8. Santosh Kumar (2010) Internet usage among dental students at a private dental institution.

9. (2016) International Journal of Scientific \& Engineering Research $7(10)$.

10. https://www.ijser.org/researchpaper/Impact-of-Internet-Usage-onthe-Academic-Performance-of-undergraduate-students.

11. B Laite (2004) Internet Use Survey: Analysis 2000.

12. OP Mashra (2005) Internet Utilization Pattern of Undergraduate Students, University News 43(13): 8-12.

\section{Your next submission with Juniper Publishers will reach you the below assets}

- Quality Editorial service

- Swift Peer Review

- Reprints availability

- E-prints Service

- Manuscript Podcast for convenient understanding

- Global attainment for your research

- Manuscript accessibility in different formats

( Pdf, E-pub, Full Text, Audio)

- Unceasing customer service

Track the below URL for one-step submission https://juniperpublishers.com/online-submission.php 